\title{
Effect of vagotomy on the gastric secretion of acid chloride and pepsin in response to an antral stimulus and to insulin and maximal histamine stimulation
}

\author{
F. I. TOVEY, M. SWAMINATHAN, K. PARKER, AND A. DANIELL \\ From the Surgical Department, Holdsworth Memorial Hospital, Mysore City, and the \\ Central Food Technological Research Institute, Mysore City, South India
}

In this investigation the secretory response of the stomach to an antral stimulus followed by insulin and then histamine stimulation before and after vagotomy has been estimated in order to determine: (1) the effect of vagotomy on 'endogenous' gastric secretion resulting from antral stimulation compared with its effect on 'exogenous' secretion following insulin and histamine injections; (2) the effect of vagotomy on pepsin secretion compared with its effect on acid secretion; (3) the effect of vagotomy on total chloride secretion; and (4) whether after selective vagotomy any vagal innervation may reach the stomach via the coeliac plexus and greater curve resulting in a greater response to stimuli than that obtained after total vagotomy.

\section{METHOD}

It was not possible to use a continuous aspiration technique because, in order to determine the antral response, it was necessary that the antrum should be stimulated by a constant amount of the stimulating fluid for a constant time. Instead the dye dilution technique, as described by Brooks, Erskine, Gephart, Swaim, and Moore (1950), was used. At the beginning of every 10 minutes $100 \mathrm{ml}$ of fluid containing phenol red $(7 \mathrm{mg} / \mathrm{l}$.) was injected into the stomach and the stomach was completely emptied by aspiration at the end of the 10-minute period. From the concentration of the dye in the aspirate it was possible to calculate both the volume of juice secreted and also the amount that had emptied from the stomach. It was then possible to calculate the actual concentration and quantity of acid, chloride, and pepsin that had been secreted during the period.

Both sodium bicarbonate and peptone were used as antral stimulants because there is evidence that these act on the antral mucosa in different ways (Celestin, 1966). The effect of peptone is abolished by Lignocaine solution $3 \%$ whereas the effect of sodium bicarbonate is unaltered, suggesting that peptone acts through neuroreceptors and sodium bicarbonate acts directly on the mucosal cells.
There was thus a possibility that vagotomy might have a different effect on each of these stimuli.

\section{PROCEDURE}

The investigations were done on South Indian duodenal ulcer patients who underwent vagotomy and pyloroplasty.

Approximately equal numbers of total and selective vagotomies were done more or less alternately.

The preoperative examination was done immediately before operation when the ulcer was active and the postoperative examination three months after vagotomy on as many patients as it was possible to follow up. All patients had had a negative postoperative Hollander insulin test, ie, the vagotomy was complete.

The patient was kept on a liquid diet for 24 hours to avoid the tube becoming blocked by rice particles.

A radioopaque tube was passed at 7.30 am and positioned under $x$-ray control so that the distal end lay in the pyloric antrum.

The patient was asked to remain lying on the left side to encourage the gastric secretions to remain in the stomach, but during the aspirations he was turned onto the right side.

BASAL SECRETION Five runs of $100 \mathrm{ml}$ of $\mathrm{N}$ saline with phenol red were injected through the tube and aspirated. The last three aspirates were used for analysis.

ANTRAL PHASE The stomach was washed out twice with $100 \mathrm{ml}$ of water to remove any acid from the antral mucosa and then $100 \mathrm{ml}$ of either $3.5 \%$ sodium bicarbonate or $10 \%$ peptone solution containing phenol red was instilled. This was aspirated after 10 minutes. Then $100 \mathrm{ml}$ of $\mathrm{N}$ saline with phenol red was injected through the tube and aspirated after a further 10 minutes.

INSULIN PHASE Soluble insulin was given intravenously (15 units for patients weighing 100 to $120 \mathrm{lb} ; 10$ units for patients under $100 \mathrm{lb}$ ), and the stomach was emptied after 10 minutes, the aspirate being discarded. Three runs of $100 \mathrm{ml}$ of $\mathrm{N}$ saline with phenol red were injected through the tube and aspirated after 10 minutes. 
MAXIMAL HISTAMINE STIMULATION Fifty mg of mepyramine maleate was injected intramuscularly. After 30 minutes the stomach was emptied and histamine $(0.04 \mathrm{mg} / \mathrm{kg}$ body weight) was given intramuscularly. Then four runs of $100 \mathrm{ml}$ of $\mathrm{N}$ saline with phenol red were injected through the tube and aspirated after 10 minutes each time.

\section{RECORDING OF RESULTS}

For basal secretion the mean of the last three aspirates was taken. Normal saline itself is a mild antral stimulant so the figures obtained were not strictly basal, but were satisfactory for purposes of comparison. The figures recorded for antral stimulation were those obtained from the aspirate taken at the end of the period of instillation of the sodium bicarbonate or peptone solution. During the periods of insulin and histamine stimulation the peak 10-minute figures have been taken and also the peak 30-minute maximal histamine responses.

The acid response to peptone stimulation often persisted longer, even lasting into the insulin phase, leading to higher figures for this phase than those obtained after sodium bicarbonate stimulation. For this reason the insulin response following peptone and following sodium bicarbonate stimulation have been recorded separately.

The method used for pepsin estimation was that of

TABLE I

PEAK CONCENTRATIONS AND OUTPUTS BEFORE AND AFTER VAGOTOMY

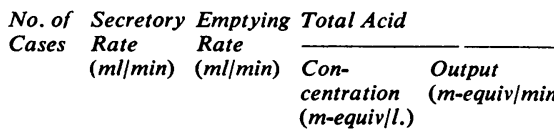

\begin{tabular}{|c|c|c|c|c|c|c|c|c|c|c|}
\hline & $\begin{array}{l}\text { DU } \\
\text { Pre-op }\end{array}$ & 97 & $\begin{array}{r}3.8 \\
\pm 1.5\end{array}$ & $\begin{array}{r}7 \cdot 5 \\
\pm 2 \cdot 8\end{array}$ & $\begin{array}{r}64 \\
\pm 30\end{array}$ & $\begin{array}{r}0.24 \\
\pm \cdot 10\end{array}$ & $\begin{array}{r}116 \\
\pm 33\end{array}$ & $\begin{array}{r}0.42 \\
\pm \cdot 17\end{array}$ & $\begin{array}{r}2.8 \\
\pm 1 \cdot 4\end{array}$ & $\begin{array}{r}9.4 \\
\pm 3.9\end{array}$ \\
\hline \multirow[t]{3}{*}{ Basal } & TV & 36 & $\begin{array}{r}2 \cdot 6 \\
\pm 1 \cdot 3\end{array}$ & $\begin{array}{r}6 \cdot 3 \\
\pm 2 \cdot 7\end{array}$ & $\begin{array}{r}31 \\
\pm 16\end{array}$ & $\begin{array}{c}0.07 \\
\pm .038\end{array}$ & $\begin{array}{r}106 \\
\pm 46\end{array}$ & $\begin{array}{r}0.25 \\
\pm \cdot 14\end{array}$ & $\begin{array}{r}2.2 \\
\pm 1.8\end{array}$ & $\begin{array}{r}4 \cdot 1 \\
\pm 2 \cdot 7\end{array}$ \\
\hline & SV & 33 & $\begin{array}{r}2.7 \\
\pm 1.4\end{array}$ & $\begin{array}{r}6.7 \\
\pm 2.5\end{array}$ & $\begin{array}{r}33 \\
\pm 6 \cdot 3\end{array}$ & $\begin{array}{c}0.08 \\
\pm .059\end{array}$ & $\begin{array}{r}106 \\
\pm 43\end{array}$ & $\begin{array}{r}0.27 \\
\pm \cdot 16\end{array}$ & $\begin{array}{c}2.0 \\
\pm \cdot 44\end{array}$ & $\begin{array}{r}3.6 \\
\pm 2.3\end{array}$ \\
\hline & $\begin{array}{l}\text { DU } \\
\text { Pre-op }\end{array}$ & 43 & $\begin{array}{r}3 \cdot 8 \\
\pm 2 \cdot 1\end{array}$ & $\begin{array}{r}6.5 \\
\pm 3 \cdot 2\end{array}$ & & & $\begin{array}{r}238 \\
\pm 99\end{array}$ & $\begin{array}{r}0 \cdot 75 \\
\pm \cdot 28\end{array}$ & $\begin{aligned} & 3.5^{1} \\
\pm & 1.6\end{aligned}$ & $\begin{array}{r}12.9: \\
\pm 5.0\end{array}$ \\
\hline \multirow[t]{3}{*}{$\begin{array}{l}\text { Antral } \\
\left(\mathrm{NaHCO}_{3}\right)\end{array}$} & TV & 18 & $\begin{array}{r}2 \cdot 7 \\
\pm 1 \cdot 2\end{array}$ & $\begin{array}{r}5 \cdot 7 \\
\pm 2 \cdot 7\end{array}$ & & & $\begin{array}{r}235 \\
\pm 95\end{array}$ & $\begin{array}{r}0.58 \\
\pm \cdot 17\end{array}$ & $\begin{aligned} & 0.95^{1} \\
\pm & 4.0\end{aligned}$ & $\begin{array}{r}2 \cdot 0^{1} \\
\pm 1 \cdot 0\end{array}$ \\
\hline & SV & 15 & $\begin{array}{r}2.1 \\
\pm 1.0\end{array}$ & $\begin{array}{r}5.4 \\
\pm 3.1\end{array}$ & & & $\begin{array}{r}289 \\
\pm 94\end{array}$ & $\begin{array}{r}0.54 \\
+.19\end{array}$ & 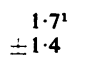 & $\begin{array}{r}2 \cdot 7^{1} \\
\pm 2 \cdot 1\end{array}$ \\
\hline & $\begin{array}{l}\text { DU } \\
\text { Pre-op }\end{array}$ & 41 & $\begin{array}{r}4 \cdot 8 \\
\pm 2 \cdot 3\end{array}$ & $\begin{array}{r}7 \cdot 8 \\
\pm 3 \cdot 1\end{array}$ & $\begin{array}{r}159 \\
+54.5\end{array}$ & $\begin{array}{r}0.73 \\
\pm \cdot 37\end{array}$ & $\begin{array}{r}185 \\
\pm 53\end{array}$ & $\begin{array}{r}0 \cdot 84 \\
\pm \cdot 37\end{array}$ & $\begin{array}{r}3.7 \\
\pm 1.6\end{array}$ & $\begin{array}{r}15.9 \\
\pm 6.6\end{array}$ \\
\hline \multirow[t]{3}{*}{$\begin{array}{l}\text { Antra! } \\
\text { (peptone) }\end{array}$} & TV & 18 & $\begin{array}{r}3 \cdot 1 \\
\pm 1 \cdot 0\end{array}$ & $\begin{array}{r}6 \cdot 7 \\
\pm 2 \cdot 8\end{array}$ & $\begin{array}{r}140 \\
\pm 14.6\end{array}$ & $\begin{array}{r}0.41 \\
\pm \cdot 14\end{array}$ & $\begin{array}{r}177 \\
\pm 41\end{array}$ & $\begin{array}{r}0.53 \\
\pm \cdot 16\end{array}$ & 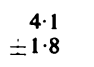 & $\begin{array}{r}11 \cdot 7 \\
\pm 4 \cdot 1\end{array}$ \\
\hline & SY & 18 & $\begin{array}{r}3.4 \\
\pm 1 \cdot 6\end{array}$ & $\begin{array}{r}6.8 \\
\pm \\
\pm 2.9\end{array}$ & $\begin{array}{l}156 \\
\pm 13 \cdot 7\end{array}$ & $\begin{array}{r}0.51 \\
\pm .25\end{array}$ & $\begin{array}{r}189 \\
\pm 40\end{array}$ & $\begin{array}{r}0 \cdot 62 \\
\pm \cdot 27\end{array}$ & $\begin{array}{r}5 \cdot 1 \\
\pm 3 \cdot 1\end{array}$ & $\begin{array}{r}15 \cdot 1 \\
\pm 6 \cdot 2\end{array}$ \\
\hline & $\begin{array}{l}\text { DU } \\
\text { Pre-op }\end{array}$ & 43 & $\begin{array}{r}5 \cdot 8 \\
\pm 3 \cdot 2\end{array}$ & $\begin{array}{r}7.9 \\
\pm 3.8\end{array}$ & $\begin{array}{c}78 \\
\pm 33 \cdot 9\end{array}$ & $\begin{array}{r}0.42 \\
\pm .29\end{array}$ & $\begin{array}{r}142 \\
\pm 48\end{array}$ & $\begin{array}{r}0 \cdot 74 \\
\pm \cdot 36\end{array}$ & $\begin{array}{r}3.6 \\
\pm 1.3\end{array}$ & $\begin{array}{r}18 \cdot 1 \\
\pm 8 \cdot 6\end{array}$ \\
\hline \multirow[t]{3}{*}{$\begin{array}{l}\text { Insulin } \\
\text { (post-NaHCO })\end{array}$} & TV & 18 & $\begin{array}{r}2 \cdot 8 \\
\pm 1 \cdot 1\end{array}$ & $\begin{array}{r}5 \cdot 3 \\
\pm 2 \cdot 0\end{array}$ & $\begin{array}{c}22 \\
\pm 13.8\end{array}$ & $\begin{array}{r}0.07 \\
\pm .05\end{array}$ & $\begin{array}{r}124 \\
\pm 71\end{array}$ & $\begin{array}{r}0 \cdot 31 \\
\pm \cdot 17\end{array}$ & $\begin{array}{r}1.5 \\
\pm 1.3\end{array}$ & $\begin{array}{r}3.5 \\
\pm 4.2\end{array}$ \\
\hline & SV & 15 & $\begin{array}{r}3 \cdot 3 \\
\pm 1 \cdot 4\end{array}$ & $\begin{array}{r}4 \cdot 1 \\
\pm 2 \cdot 8\end{array}$ & $\begin{array}{l}25 \\
\pm 12 \cdot 5\end{array}$ & $\begin{array}{r}0.08 \\
\pm .06\end{array}$ & $\begin{array}{r}111 \\
\pm 37\end{array}$ & $\begin{array}{r}0 \cdot 36 \\
\pm \cdot 23\end{array}$ & $\begin{array}{l}1.4 \\
\pm .93\end{array}$ & $\begin{array}{r}4 \cdot 1 \\
\pm 2 \cdot 8\end{array}$ \\
\hline & $\begin{array}{l}\text { DU } \\
\text { Pre-op }\end{array}$ & 41 & $\begin{array}{r}5 \cdot 5 \\
\pm 2 \cdot 1\end{array}$ & $\begin{array}{r}8 \cdot 2 \\
\pm 3 \cdot 8\end{array}$ & $\begin{array}{r}103 \\
\pm 37\end{array}$ & $\begin{array}{r}0.56 \\
\pm .27\end{array}$ & $\begin{array}{r}147 \\
\pm 39\end{array}$ & $\begin{array}{r}0 \cdot 78 \\
\pm \cdot 32\end{array}$ & $\begin{array}{r}2.4 \\
\pm 1.0\end{array}$ & $\begin{array}{r}12.6 \\
\pm 5 \cdot 7\end{array}$ \\
\hline \multirow[t]{3}{*}{$\begin{array}{l}\text { Insulin } \\
\text { (post-peptone) }\end{array}$} & TV & 18 & $\begin{array}{c}3.0 \\
\pm 0.94\end{array}$ & $\begin{array}{c}\quad 6 \cdot 3 \\
\pm 0 \cdot 77\end{array}$ & $\begin{array}{r}44 \\
\pm 26\end{array}$ & $\begin{array}{r}0.13 \\
\pm .02\end{array}$ & $\begin{array}{r}134 \\
\pm 32\end{array}$ & $\begin{array}{r}0 \cdot 39 \\
\pm \cdot 12\end{array}$ & $\begin{array}{r}1.74 \\
\pm .94\end{array}$ & $\begin{array}{r}4 \cdot 8 \\
\pm 2 \cdot 7\end{array}$ \\
\hline & SY & 18 & $\begin{array}{r}3.2 \\
\pm 1.9\end{array}$ & $\begin{array}{r}5 \cdot 8 \\
\pm 4 \cdot 0\end{array}$ & $\begin{array}{r}50 \\
\pm 27\end{array}$ & $\begin{array}{r}0 \cdot 16 \\
\pm \cdot 03\end{array}$ & $\begin{array}{r}135 \\
\pm 45\end{array}$ & $\begin{array}{r}0 \cdot 43 \\
\pm \cdot 17\end{array}$ & $\begin{array}{r}1.9 \\
\pm 1.5\end{array}$ & $\begin{array}{r}5 \cdot 4 \\
\pm 2 \cdot 2\end{array}$ \\
\hline & $\begin{array}{l}\text { DU } \\
\text { Pre-op }\end{array}$ & 86 & $\begin{array}{r}8 \cdot 1 \\
\pm 4 \cdot 2\end{array}$ & $\begin{array}{r}10 \cdot 8 \\
\pm 4 \cdot 0\end{array}$ & $\begin{array}{r}104 \\
\pm 24\end{array}$ & $\begin{array}{r}0.85 \\
\pm .28\end{array}$ & $\begin{array}{r}145 \\
\pm 20\end{array}$ & $\begin{array}{r}1 \cdot 16 \\
\pm \cdot 38\end{array}$ & $\begin{array}{c}3 \cdot 2 \\
\pm \cdot 71\end{array}$ & $\begin{array}{r}25 \cdot 1 \\
\pm 6 \cdot 8\end{array}$ \\
\hline \multirow[t]{2}{*}{$\begin{array}{l}\text { Maximal } \\
\text { histamine }\end{array}$} & TY & 36 & $\begin{array}{r}3 \cdot 8 \\
\pm 1 \cdot 1\end{array}$ & $\begin{array}{r}6 \cdot 3 \\
\pm 3 \cdot 8\end{array}$ & $\begin{array}{r}51 \\
\pm 30\end{array}$ & $\begin{array}{r}0.20 \\
\pm \cdot 13\end{array}$ & $\begin{array}{r}132 \\
\pm 34\end{array}$ & $\begin{array}{r}0.50 \\
\pm \cdot 15\end{array}$ & $\begin{array}{r}3 \cdot 3 \\
\pm 2 \cdot 5\end{array}$ & $\begin{array}{r}8.3 \\
\pm 6.0\end{array}$ \\
\hline & SV & 33 & $\begin{array}{r}4 \cdot 2 \\
\pm 1 \cdot 3\end{array}$ & $\begin{array}{r}6.0 \\
\pm 3.1\end{array}$ & $\begin{array}{r}48 \\
\pm 24\end{array}$ & $\begin{array}{r}0.21 \\
\pm \cdot 15\end{array}$ & $\begin{array}{r}127 \\
\pm 25\end{array}$ & $\begin{array}{r}0.53 \\
\pm \cdot 18\end{array}$ & $\begin{array}{r}2 \cdot 2 \\
\pm .85\end{array}$ & $\begin{array}{r}9 \cdot 1 \\
\pm 4 \cdot 4\end{array}$ \\
\hline
\end{tabular}

$\mathrm{TY}=$ total vagotomy.

SV $=$ selective vagotomy.

Figures for 10-minute period after instillation of $\mathrm{NaHCO}_{3}$.

Standard deviations are shown. 
Anson and Mirsky, using human plasma as the protein substrate in place of oxycarboxyhaemoglobin (Sen and Roy, 1963).

\section{FINDINGS}

The findings are summarized in Tables I, II, and III. SECRETORY RATE The volume of basal secretion was reduced by approximately $25 \%$ after vagotomy, and the volume following insulin and histamine stimulation was considerably reduced (approximately 50\%). The volume following antral stimulation was reduced in some and increased in others, a reduction occurring more frequently than an increase, resulting in an overall decrease in the mean volume.

EMPTYING RATE The emptying rates exceeded the secretory rates and were reduced by vagotomy, becoming almost constant throughout. It had been suggested that the preservation of the vagal nerve supply to the duodenum might have had some effect on the emptying rate after selective vagotomy but there was no difference between selective and total vagotomy. It should be noted that these figures refer to the emptying rate of fluid and not of food contents.

ACID SECRETION The figures for total acid only are given. It was not possible to do a titration for acid in the sodium bicarbonate series because the sodium bicarbonate itself neutralized much of the hydrochloric acid so that only the figures for total chloride excretion are available.

Vagotomy had no constant effect on the concentration of acid following antral stimulation with peptone. The concentration of basal acid was

TABLE II

STATISTICAL ANALYSIS OF DATA FOR CONCENTRATION IN TABLE I

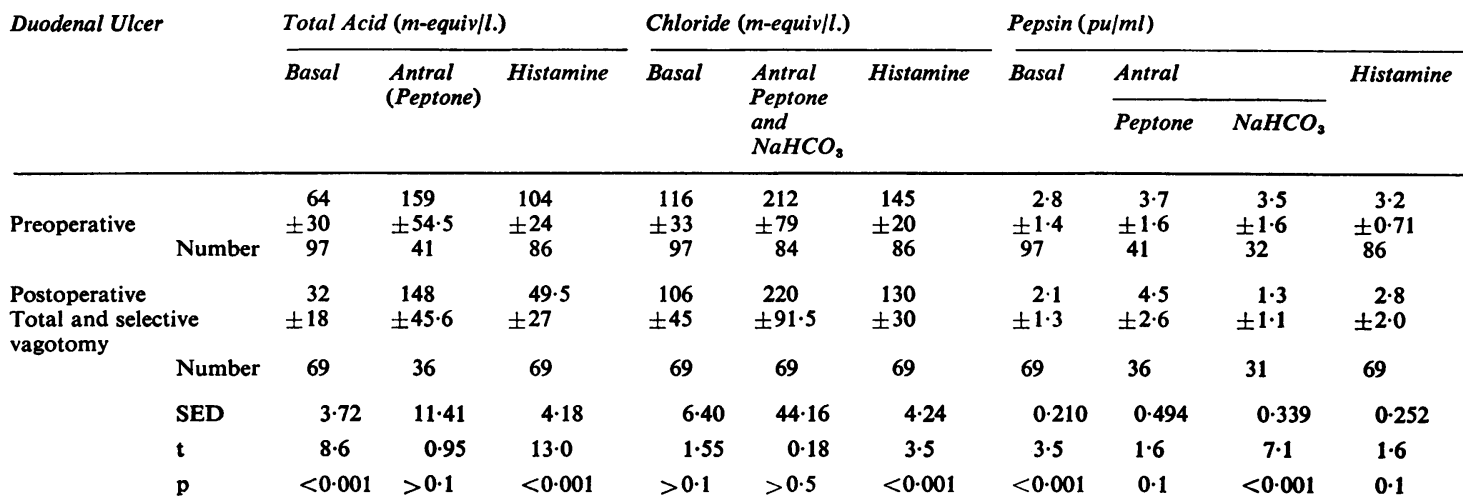

TABLE III

STATISTICAL ANALYSIS OF DATA FOR OUTPUT IN TABLE I

\begin{tabular}{|c|c|c|c|c|c|c|c|c|c|c|}
\hline \multirow[t]{3}{*}{ Duodenal Ulcer } & \multicolumn{3}{|c|}{ Total Acid (m-equiv/min) } & \multicolumn{3}{|c|}{ Chloride (m-equiv/min) } & \multicolumn{4}{|c|}{ Pepsin (pu/min) } \\
\hline & \multirow[t]{2}{*}{ Basal } & \multirow{2}{*}{$\begin{array}{l}\text { Antral } \\
\text { (Peptone) }\end{array}$} & \multirow[t]{2}{*}{ Histamine } & \multirow[t]{2}{*}{ Basal } & \multirow{2}{*}{$\begin{array}{l}\text { Antral } \\
\text { Peptone } \\
\text { and } \\
\mathrm{NaCHO}_{3}\end{array}$} & \multirow[t]{2}{*}{ Histamine } & \multirow[t]{2}{*}{ Basal } & \multicolumn{2}{|l|}{ Antral } & \multirow[t]{2}{*}{ Histamine } \\
\hline & & & & & & & & Peptone & $\mathrm{NaHCO}_{3}$ & \\
\hline $\begin{array}{l}\text { Preoperative } \\
\text { Number }\end{array}$ & $\begin{array}{l}0.24 \\
\pm 0 \cdot 10 \\
97\end{array}$ & $\begin{array}{r}0.73 \\
\pm 0.37 \\
41\end{array}$ & $\begin{aligned} & 0.85 \\
& \pm 0.28 \\
& 86\end{aligned}$ & $\begin{array}{r}0.42 \\
\pm 0.17 \\
97\end{array}$ & $\begin{array}{l}0.79 \\
\pm 0.33 \\
84\end{array}$ & $\begin{array}{l}1 \cdot 16 \\
\pm 0.38 \\
86\end{array}$ & $\begin{array}{r}9 \cdot 4 \\
\pm 3 \cdot 9 \\
97\end{array}$ & $\begin{array}{c}15.9 \\
\pm 6 \cdot 6 \\
41\end{array}$ & $\begin{array}{r}12 \cdot 9 \\
\pm 5 \cdot 0 \\
32\end{array}$ & $\begin{array}{c}25 \cdot 1 \\
\pm 6 \cdot 8 \\
86\end{array}$ \\
\hline $\begin{array}{l}\text { Postoperative } \\
\text { Total and selective } \\
\text { vagotomy }\end{array}$ & $\begin{array}{r}0.075 \\
\pm 0.054\end{array}$ & $\begin{array}{r}0.46 \\
\pm 0.21\end{array}$ & $\begin{array}{r}0.21 \\
\pm 0 \cdot 14\end{array}$ & $\begin{array}{r}0.26 \\
\pm 0 \cdot 15\end{array}$ & $\begin{array}{r}0.57 \\
\pm 0.21\end{array}$ & $\begin{array}{r}0.51 \\
\pm 0.17\end{array}$ & $\begin{array}{r}3 \cdot 9 \\
\pm 2 \cdot 5\end{array}$ & $\begin{array}{r}13 \cdot 4 \\
\pm 5 \cdot 5\end{array}$ & $\begin{array}{r}2.5 \\
\pm 1 \cdot 4\end{array}$ & $\begin{array}{r}8 \cdot 7 \\
\pm 5 \cdot 3\end{array}$ \\
\hline Number & 69 & 36 & 69 & 69 & 69 & 69 & 69 & 36 & 31 & 69 \\
\hline SED & 0.001205 & 0.02131 & 0.3418 & 0.0254 & 0.04421 & 0.4526 & 0.4952 & $1 \cdot 38$ & 0.9272 & 0.9715 \\
\hline $\mathbf{t}$ & 137 & $7 \cdot 5$ & 60 & 8 & 5 & $14 \cdot 4$ & $12 \cdot 9$ & $1 \cdot 8$ & $11 \cdot 2$ & $16 \cdot 1$ \\
\hline $\mathbf{p}$ & $<0.001$ & $<0.001$ & $<0.001$ & $<0.001$ & $<0.001$ & $<0.001$ & $<0.001$ & 0.1 & $<0.001$ & $<0.001$ \\
\hline
\end{tabular}


reduced and that following insulin and histamine stimulation was considerably reduced. The combination of a fall in concentration and a fall in volume resulted in a considerable fall in output in the basal, insulin, and histamine groups.

In Table IV the figures in 32 cases for the preoperative and postoperative total acid outputs in the peptone series are compared with the peak histamine outputs. The output following antral stimulation with peptone was reduced by vagotomy in some and increased in others, a larger number showing a fall resulting in a significant fall in the mean output value which, however, was about double the mean postoperative histamine output. These changes are seen clearly in the scatter graphs shown in Fig. 1 for the peptone series and for the whole series following histamine stimulation.

There is no indication from the figures in Table IV that patients with a high antral response relative to the maximal histamine response preoperatively were more likely to have a high postoperative antral response.

TABLE IVa

TOTAL ACID OUTPUT IN RESPONSE TO PEPTONE $(10 \%$ SOLUTION) COMPARED WITH PEAK HISTAMINE OUTPUT (M-EQUIV HCL/MIN)

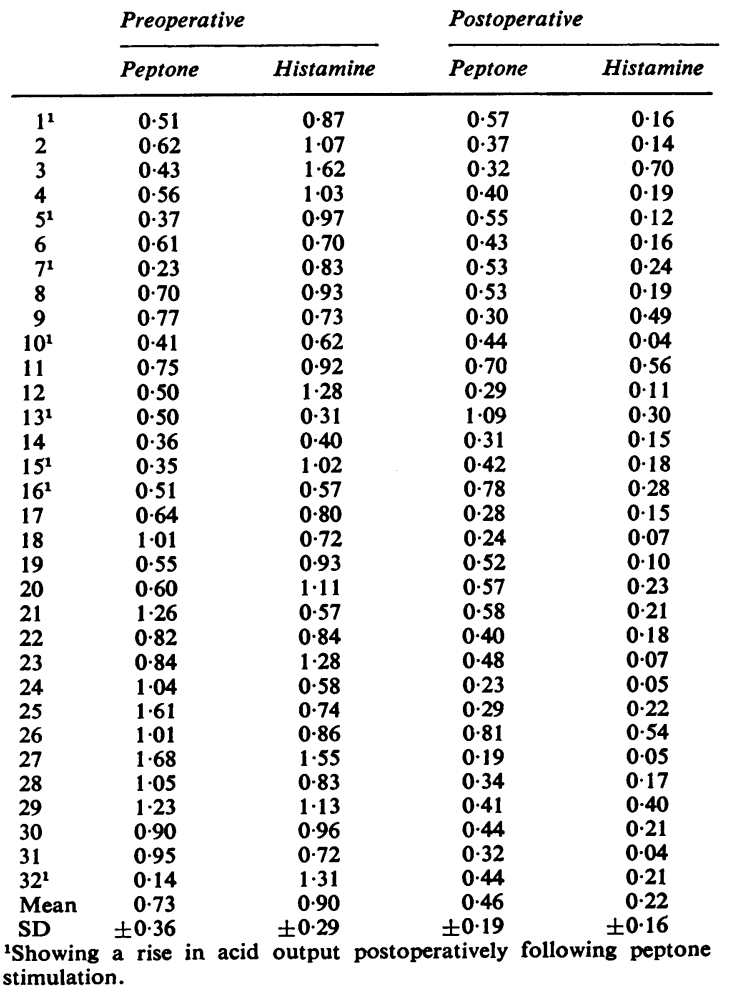

TABLE IVb APPLICATION OF T TEST

\begin{tabular}{ccccc}
$\begin{array}{l}\text { Preoperative } \\
\text { Peptone/ } \\
\text { Histamine }\end{array}$ & $\begin{array}{l}\text { Preoperative } \\
\text { Peptone/ } \\
\text { Postoperative } \\
\text { Peptone }\end{array}$ & $\begin{array}{l}\text { Preoperative } \\
\text { Histamine/ } \\
\text { Postoperative } \\
\text { Histamine }\end{array}$ & $\begin{array}{l}\text { Postoperative } \\
\text { Peptonel }\end{array}$ & Histamine \\
\hline t & 2.01 & 3.89 & 11.6 & 17.5 \\
p & 0.05 & $<0.001$ & $<0.001$ & $<0.001$
\end{tabular}

The individual figures for chloride concentration and output were increased in some cases after vagotomy in both the peptone and sodium bicarbonate series which suggests that the figures for acid also were increased postoperatively in some patients in the sodium bicarbonate group in the same way as in the peptone group.

CHLORIDE SECRETION Total chloride concentrations were little affected by vagotomy and the output charts reflect the changes in the volumes of the secretion. This means that after vagotomy, when there is a fall in hydrochloric acid concentration, it is compensated for by an increase in other 'neutral chlorides'. This means that the place of $\mathrm{H}^{+}$ions is taken by other cations and the number of $\mathrm{Cl}^{-}$ions being produced remains unaltered. Glass, Boyd, Drekter, and Heisler (1952) and Gamble and McIver (1928) suggest that sodium ions are the variable cations present in 'neutral chloride' and that the other cations present are small in number and constant in concentration. These changes in neutral chloride, ie, the difference in concentration between total chloride and total acid, are shown in Table V. It will be noted that the concentrations of neutral chloride are much lower in the antral phase after peptone

TABLE V

NEUTRAL CHLORIDE (M-EQUIV/L.)

\begin{tabular}{ccccc} 
& Basal & $\begin{array}{c}\text { Antral } \\
\text { (Peptone) }\end{array}$ & Insulin & $\begin{array}{c}\text { Maximal } \\
\text { Histamine }\end{array}$ \\
\hline Duodenal ulcer & 54 & 17 & 50 & 39 \\
SD & \pm 32 & \pm 12 & \pm 30 & \pm 20 \\
After vagotomy & 74 & 32 & 89 & 83 \\
SD & \pm 45 & \pm 27 & \pm 51 & \pm 30 \\
Statistical analysis & & & & \\
SED & 6.564 & 4.913 & 6.493 & 4.260 \\
t & 3.04 & 3.05 & 7.54 & 10.32 \\
P & 0.005 & 0.005 & 0.001 & 0.001
\end{tabular}

TABLE Va

RATIO OF NEUTRAL CHLORIDE/TOTAL CHLORIDE

\begin{tabular}{lcccc} 
& $\begin{array}{l}\text { Basal } \\
(\%)\end{array}$ & $\begin{array}{l}\text { Antral } \\
(\text { Peptone }) \\
(\%)\end{array}$ & $\begin{array}{l}\text { Insulin } \\
(\%)\end{array}$ & $\begin{array}{l}\text { Maximal } \\
\text { Histamine } \\
(\%)\end{array}$ \\
\hline $\begin{array}{l}\text { Preoperative } \\
\text { Postoperative }\end{array}$ & 45 & 9 & 35 & 27 \\
\hline 70 & 17 & 66 & 63
\end{tabular}




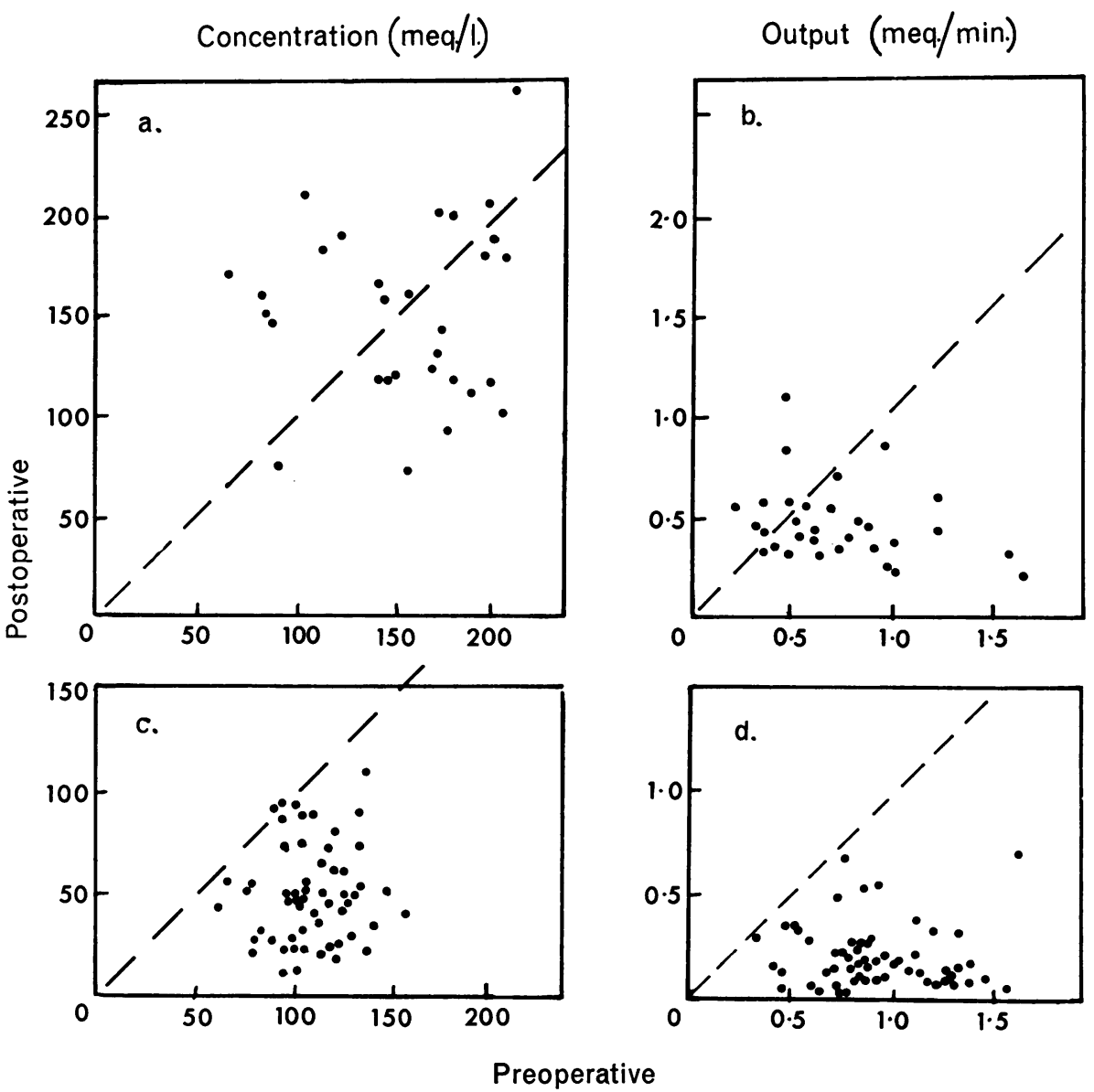

FIG. 1. Effect of vagotomy on acid concentration and output in response to $10 \%$ peptone stimulation ( $a$ and $b$ ) and maximal histamine stimulation, whole series ( $c$ and $d$ ).

stimulation in which the total chloride concentration itself is greatly increased.

PEPSIN There was a significant reduction in pepsin concentration in the basal and insulin series after vagotomy but less than the reduction occurring with acid secretion. There was no significant reduction in concentration with histamine stimulation. The corresponding outputs further reflect the reductions in secretory volumes reported already.

In the peptone series there was no significant change in pepsin concentration or output after vagotomy. In the sodium bicarbonate series the results are equivocal. In this series the figures for the 10-minute period after the period of instillation of the solution have been taken. This was to avoid errors due to inactivation of pepsin by the sodium bicarbonate. Even so, the $p \mathrm{H}$ in the postvagotomy patients remained high for several aspirates after the sodium bicarbonate stimulation. This means that the fall in pepsin concentration and output shown may be erroneous. This is supported by the fact that the few postoperative patients who had a low $p \mathrm{H}$ of the second aspirate after sodium bicarbonate instillation showed quite high pepsin concentrations and outputs. The preoperative patients, however, did not show this high $p H$ in the second aspirate after sodium bicarbonate and the pepsin concentration and outputs are similar to those in the peptone series.

PEAK MAXIMAL (30-MINUTE) HISTAMINE RESPONSE In Fig. 2 the preoperative maximal histamine response in 63 patients has been plotted against the 


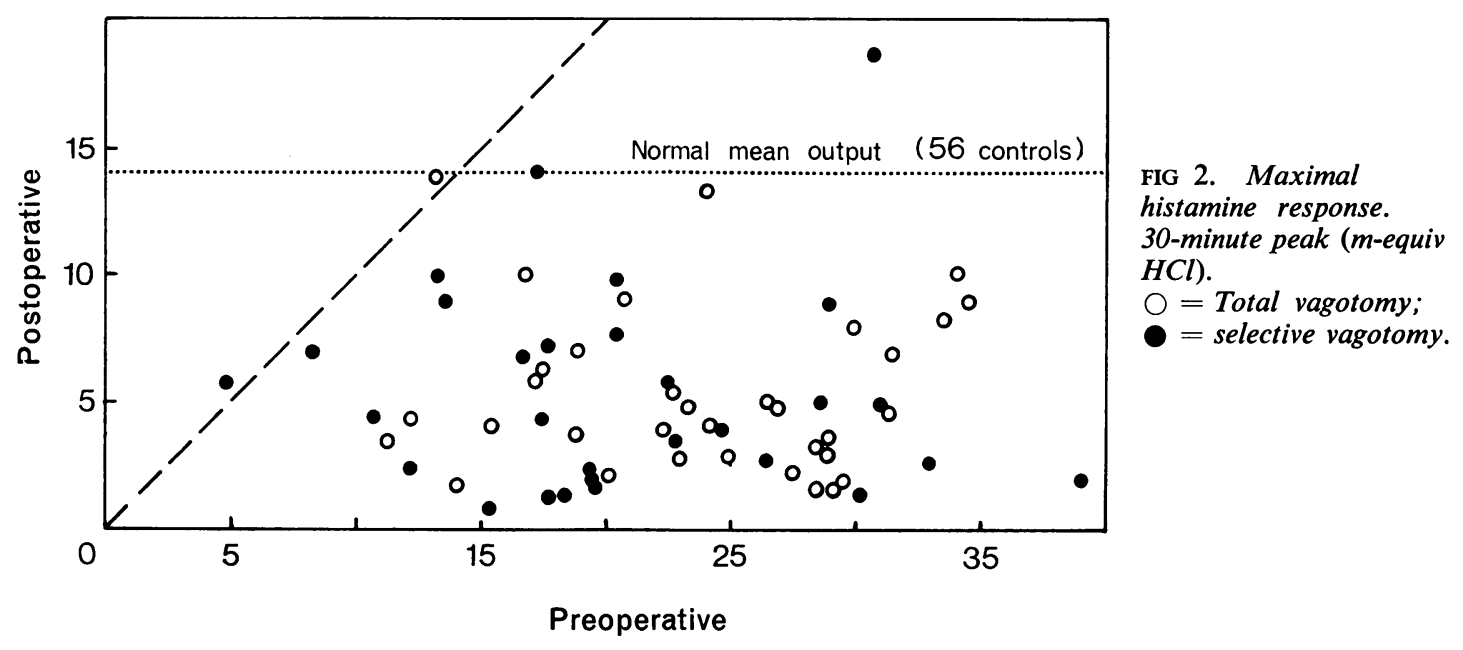

postoperative response. The patients with the higher preoperative values tended to show the greater fall so that in nearly all cases the postoperative values fell below the mean average of the normal population as represented by a control group. The mean values are shown in Table VI.

\section{TABLE VI}

THIRTY-MINUTE MAXIMAL HISTAMINE RESPONSE (M-EQUIV $\mathrm{HCl}$ )

\begin{tabular}{|c|c|c|c|}
\hline & $\begin{array}{l}\text { Controls } \\
\text { (56) }\end{array}$ & $\begin{array}{l}\text { Duodenal } \\
\text { Ulcer } \\
\text { Preoperatively } \\
\text { (63) }\end{array}$ & $\begin{array}{l}\text { Postvagotomy } \\
\text { (63) }\end{array}$ \\
\hline & $\begin{array}{r}14 \cdot 06 \\
S D \pm 8 \cdot 21\end{array}$ & $\begin{array}{r}22 \cdot 12 \\
\mathrm{SD} \pm 7 \cdot 2\end{array}$ & $\begin{array}{r}5 \cdot 27 \\
\mathrm{SD} \pm 3 \cdot 57\end{array}$ \\
\hline & Control/DU & $\begin{array}{l}\text { Preoperativel } \\
\text { Postoperative }\end{array}$ & $\begin{array}{l}\text { Controll } \\
\text { Postoperative }\end{array}$ \\
\hline $\begin{array}{l}\text { SED } \\
t \\
P\end{array}$ & $\begin{array}{l}1 \cdot 134 \\
7 \cdot 1 \\
<0.001\end{array}$ & $\begin{array}{l}0.5330 \\
31.6 \\
<0.001\end{array}$ & $\begin{array}{l}1 \cdot 186 \\
7 \cdot 4 \\
<0.001\end{array}$ \\
\hline
\end{tabular}

COMPARISON BETWEEN TOTAL AND SELECTIVE VAGOTOMY No difference was found between total and selective vagotomy in any of the series. The concentration and output for acid, chloride and pepsin were charted separately on graphs for total and selective vagotomy showing the basal, antral, insulin, and histamine phases of secretion and no difference was found in any of the graphs. This is illustrated by the graph in Fig. 2 showing 30-minute maximal histamine responses where different symbols have been used for total and selective vagotomy. There is no evidence that any vagal outflow reaches the stomach via the coeliac plexus and greater curve after selective vagotomy.

\section{COMMENTS}

The high concentration of acid following antral stimulation lends weight to the evidence that gastrin is a very powerful stimulant of gastric secretion, but it needs to be remembered also that during the period when sodium bicarbonate or peptone were in the stomach the fluid emptying into the duodenum would not have been acid enough to cause duodenal inhibition of gastric secretion. The factor of duodenal inhibition would have been operative in the basal and insulin phases of the investigation and may have resulted in lower values for acid secretion than would have been obtained by a continuous aspiration technique. Duodenal inhibition does not occur with histamine stimulation providing that the dose given is truly maximal which makes the values comparable with those following antral stimulation. The preoperative and postoperative figures also are all comparable because the same factors in each phase would be equally at play before and after operation.

The fact that after operation the acid output following antral stimulation often exceeded the output following histamine stimulation suggests that the dose of histamine used is no longer maximal after vagotomy. This higher output has been noticed with pentagastrin in some cases by Payne, Cox, Spencer, and Cheng (1967) and by Bank, Marks, Louw, and Tigler-Wybrandi (1967). Celestin (1967) reports that after vagotomy he has found that the accepted doses of histamine are no longer maximal and that if the doses are increased higher acid outputs can be obtained, even approaching the preoperative levels.

Payne et al (1967) found that the parietal cell acid 
output in response to maximal doses of pentagastrin was reduced by $61.5 \%$ after vagotomy. The Multicentre Study (1967) gave a similar figure (67\%). This suggests that the effect of vagotomy on the parietal cells is constant and that the variable change in postoperative output in this series is more likely to be due to variation in the antral release of gastrin. With this in mind the emptying rates were reviewed, thinking that the patients with the higher postoperative antral response may have had slower emptying rates resulting in longer exposure to a concentrated solution of the stimulant, but no correlation was found.

\section{CONCLUSIONS}

Bearing in mind the four points for investigation mentioned in the introduction, the conclusions are as follows.

RELATIVE EFFECT OF VAGOTOMY ON THE ANTRUM Although vagotomy reduces the acid secretion in response to insulin and histamine it does not constantly reduce the response to antral stimulation in this series, whether the stimulus be a physical change in $p \mathrm{H}$ acting directly on the mucosal cell or a chemical stimulus (peptone) acting on the neuroreceptors. These results differ from those of other workers. Giles and Clark (1966a and b) found that vagotomy abolished the antral response to meat extract in 32 out of 40 cases. Welbourn and Burns (1964) found a $67 \%$ fall in acid output in response to meat extract after vagotomy. Celestin (1967), using a balloon tube to block the pylorus, also found that vagotomy reduced the response to Bovril but did not abolish it. The above workers, however, based their findings on the secretions aspirated during the period following the installation of the stimulant and not during the stimulation. It is possible that the weaker concentration of amino acids, etc, in the meat extracts used above resulted in a submaximal stimulus to the antrum which could be potentiated by the vagus and that the $10 \%$ peptone and $3.75 \%$ sodium bicarbonate solutions used by us may have resulted in a maximal gastrin output unaffected by vagal innervation. Harrison, Williams, Pisesky, Husain, Silbermann, Francis, and Irvine (1961), working on dogs, found that vagotomy of the antrum was much more effective in reducing the incidence of ulcers in ileal transplants into the first part of the duodenum than vagotomy of the parietal cell mass.

2 EFFECT OF VAGOTOMY ON PEPSIN SECRETION In most cases the pepsin concentration fell after vagotomy both in basal secretion and in response to insulin stimulation, but the fall was less than that which occurred in the acid concentration. There was a variable change in concentration in response to peptone and histamine stimulation. The output was reduced in response to insulin and histamine, but not constantly in response to peptone stimulation. Bitsch, Christiansen, Faber, and Rødbro (1966) also found a reduction in basal concentration and postinsulin concentration after vagotomy, but no reduction in pepsin concentration in response to histamine and felt that the fall in output after histamine was due to the reduction in secretory volume. Book, Chinn, and Beams (1952) found no reduction in pepsin concentration after vagotomy in nocturnal juice or after insulin-induced hypoglycaemia.

3 EFFECT ON TOTAL CHLORIDE SECRETION Vagotomy seems to have no effect on total chloride concentration. This agrees with the work of Davenport $(1964,1965)$ which suggests that the concentration of chloride ions remains constant, and that in gastritis and in gastric ulcer patients hydrogen ions diffuse from the gastric juice back into the mucosa and sodium ions escape.

4 EFFECT OF SELECTIVE VAGOTOMY COMPARED WITH TOTAL VAGOTOMY The results show that selective vagotomy is no less effective than total in all respects. These findings agree with those of Bank, Marks, and Louw (1966) and of Griffiths (1966), confirming that there need be no fear of a selective vagotomy being incomplete.

\section{SUMMARY}

A dye-dilution technique was used to estimate the gastric secretion of acid, chloride, and pepsin in response to antral, insulin, and histamine stimulation before and after in approximately equal numbers of cases of selective and total vagotomy.

The acid and pepsin secretions in response to antral stimulation were not uniformly depressed by vagotomy. The basal insulin and histamine secretions of acid were constantly reduced in concentration and quantity whereas, although the output of pepsin was usually reduced, the concentration was not always reduced. The mean acid output in response to antral stimulation after vagotomy was about double the output in response to maximal histamine stimulation.

The chloride concentration remained unaffected by vagotomy, suggesting that any fall in $\mathrm{H}^{+}$ions was compensated for by an increase in other cations.

No difference was found between the response to total vagotomy and the response to selective vagotomy, supporting the supposition that no vagal 
outflow reaches the stomach via the coeliac plexus and greater curve.

The fall in total acid output following maximal histamine stimulation tended to be greater in those with the higher preoperative values. The results suggest that there is no basis for a selective policy in the surgery of duodenal ulcer based on preoperative tests of maximal acid output or of antral predominance.

We wish to thank Dr H. A. B. Parpia, Director, Central Food Technological Research Institute, Mysore City, South India, for his permission to undertake this investigation and for his continued encouragement. We also thank all the staff of the Holdsworth Memorial Hospital and other friends who assisted us in so many ways. We are especially grateful to Mr Mody, MSc, of Unichem Laboratories, Bombay, for having given a generous grant to meet the cost of this investigation.

\section{REFERENCES}

Bank, S., Marks, I. N., and Louw, J. H. (1966). Gastric secretory patterns after vagotomy. Lancet, 2, 548-549.

,,--- , and Tigler-Wybrandi, N. (1967). Stimulation of gastricacid secretion by histamine, pentagastrin, and pentagastrinpropantheline after vagotomy in man. Ibid., 2, 67-69.

Bitsch, V., Christiansen, P. M., Faber, V., and Rødbro, P. (1966). Gastric secretory patterns before and after vagotomy. Ibid., 1, 1288-1291.

Book, D. T., Chinn, A. B., and Beams, A. J. (1952). Studies on pepsin secretion. II. Effect of vagal resection for duodenal ulcer. Gastroenterology, 20, 458-463.
Brooks, J. R., Erskine, J. M., Gephart, T., Swaim, O., and Moore, F. D. (1950). The chloride output rate of the human stomach in healthy subjects and ulcer patients; the effects of vagotomy and acetylcholine. Surg. Gynec. Obstet., 90, 155-170.

Celestin, L. R. (1966). Personal communication.

- (1967). Ibid.

Davenport, H. W. (1964). Functional significance of gastric mucosal barrier to sodium. Gastroenterology, 47, 142-152.

- (1965). Is the apparent hyposecretion of acid by patients with gastric ulcer a consequence of a broken barrier to diffusion of hydrogen ions into the gastric mucosa? Gut, 6, 513.

Gamble, J. L., and McIver, M. A. (1928). The acid-base composition of gastric secretions. J. exp. Med., 48, 837-847.

Giles, G. R., and Clark, C. G. (1966a). Antral function in patients with duodenal ulcer. (Abstract.) Brit. J. Surg., 53, 990.

- -1 (1966b). Gastric secretion stimulated by meat extract in man. Scand. J. Gastroent., 1, 159-166.

Glass, G. B. J., Boyd, L. J., Drekter, I. J., and Heisler, A. (1952). Studies on the non-parietal component of gastric secretion in humans. Gastroenterology, 20, 430-457.

Griffiths, C. (1966). Selective gastric vagotomy. Modern Trends in Surgery, II, pp. 1-15. Edited by W. T. Irvine. Butterworths, London.

Harrison, R. C., Williams, H. T. G., Pisesky, W., Husain, S., Silbermann, O. H., Francis, G. J., and Irvine, J. W. The relative importance of the vagus nerve, antrum, and acidsecreting mucosa in the prevention of experimental peptic ulceration. Surgery, 50, 151-160.

Multicentre Study (1967). The effect of vagotomy on gastric secretion elicited by pentagastrin in man. Lancet, 2, 534-536.

Payne, R. A., Cox, A. G., Spencer, J., and Cheng, F. C. Y. (1967). Effect of vagotomy on gastric acid secretion stimulated by pentagastrin and histamine. Brit. med.J., 4, 456-457.

Sen, S. B., and Roy, N. K. (1963). Studies on pepsin secretion in healthy subjects and ulcer patients. Indian J. med Res., 51 , 23-35.

Welbourne, R. B., and Burns, G. P. (1964). The choice of operation for duodenal ulcer on the basis of preoperative gastric secretory studies, with particular reference to the influence on antral function. 7th Congr. int. Gastroent., 1, Book 2, 163-177. 